\title{
IMPLEMENTASI PROGRAM SEKOLAH RUJUKAN MELALUI KEGIATAN MEMBATIK DALAM PERSPEKTIF SEKOLAH EFEKTIF
}

\author{
Ida Ayu Permatasari \\ Manajemen Pendidikan, Fakultas IImu Pendidikan,Universitas Negeri Surabaya \\ E-mail : idaayupermatasari6@gmail.com
}

\begin{abstract}
This study aims to describe about (1) Planning a referral school program by doing batik activities in an effective school perspective; (2) Implementation of the referral school program by doing batik activities in an effective school perspective; (3) Impact of the referral school program through batik activities at SMA Muhammadiyah 2 Surabaya. The results of the study can be explained as follows: (1) Planning which includes the appointment of schools to become referral schools, formulation of excellent referral school programs that will be compensated to other schools, and organizing formation of referral school program committees involving Principals, Deputy Principals, and Teachers. The committee served as schools appointed that will become impacted schools from SMA Muhammadiyah 2 Surabaya. There is a budget from the government and additional funds from the school for the needs of tools and materials for batik activities. (2) The implementation of the program include guidance system that is held every Friday-Saturday with an intensity of 10 meetings before the exhibition is held. The implementation of batik activities was carried out every 2-3 months. The place for batik activities at the K.H Ahmad Dahlan Mosque. The amount of participants in each school is $5-10$ students with 2 teachers to acompany them. The material of batik is also given before the practice in the field to reduce the risk of errors. (3) The impact of the referral school program through batik activities that is for referral schools can raise the good name of the school and to motivate the impacted school to have a similar program. Another impact by this activities to get achievement obtained through batik exhibitions held in another places.
\end{abstract}

Keywords : Implementation of Programs, Batik Activities, Referral School Programs

\begin{abstract}
Abstrak: Penelitian ini bertujuan untuk mendeskripsikan tentang (1) Perencanaan program sekolah rujukan melalui kegiatan membatik dalam perspektif sekolah efektif; (2) Implementasi program sekolah rujukan melalui kegiatan membatik dalam perspektif sekolah efektif; (3) Dampak program sekolah rujukan melalui kegiatan membatik di SMA Muhammadiyah 2 Surabaya. Hasil penelitian dapat dijelaskan sebagai berikut : (1) Perencanaan yang meliputi penunjukan sekolah untuk menjadi sekolah rujukan, perumusan program unggulan sekolah rujukan yang akan diimbaskan ke sekolah lain, dan pengorganisasian dalam pembentukan panitia program sekolah rujukan yang melibatkan Kepala Sekolah, Wakil Kepala Sekolah, dan Guru. Panitia bertugas untuk menunjuk sekolah yang akan menjadi sekolah imbas/binaan dari SMA Muhammadiyah 2 Surabaya. Terdapat anggaran dari pemerintah dan dana dampingan dari sekolah untuk kebutuhan alat dan bahan kegiatan membatik. (2) Implementasi program meliputi sistem pembinaan yang dilaksanakan setiap hari Jumat-Sabtu dengan intensitas 10 kali pertemuan sebelum kegiatan pameran dilakukan. Pelaksanaan kegiatan membatik dilakukan setiap 2-3 bulan sekali. Tempat pelaksanaan membatik di Mushola K.H Ahmad Dahlan. Jumlah peserta tiap sekolah yaitu 5-10 siswa dengan 2 guru pendamping. Pemberian materi tentang membatik juga diberikan sebelum praktik dilapangan guna mengurangi resiko kesalahan. (3) Dampak dari program sekolah rujukan melalui kegiatan membatik yaitu untuk sekolah rujukan dapat mengangkat nama baik sekolah dan memotivasi sekolah imbas agar memiliki program serupa. Dampak lain yaitu prestasi yang didapatkan melalui pagelaran pameran-pameran membatik yang telah diadakan di berbagai tempat.
\end{abstract}

Kata kunci: Implementasi Program, Kegiatan Membatik, Program Sekolah Rujukan 
Pada era globalisasi, kualitas pendidikan menjadi salah satu aspek penting dalam kemajuan suatu bangsa. Peningkatan kualitas ini merupakan tugas pemerintah dalam memajukan pendidikan dan dapat bersaing secara global. Tuntutan pendidikan pada abad 21 juga mengharuskan pendidikan di Indonesia melangkah dengan pesat seiring dengan perkembangan zaman. Reformasi sistem pendidikan merupakan hal yang harus dilakukan untuk menjamin peningkatan kualitas pendidikan.

Upaya pemerintah dalam penyelesaian permasalahan kualitas pendidikan, salah satunya dengan cara mendorong pemerintah daerah dan sekolah untuk memenuhi Standar Nasional Pendidikan (SNP). Badan SNP memiliki tujuan untuk menjamin mutu pendidikan nasioanal dalam rangka mencerdaskan kehidupan bangsa dan membentuk watak serta peradapan bangsa yang bermartabat. Untuk mencapai tersebut diperlukan beberapa standar nasional pendidikan yang harus terpenuhi seperti yang tertuang dalam Peraturan Pemerintah (PP) Nomor 32 Tahun 2013 dan PP Nomor 13 Tahun 2015 bahwa standar nasional pendidikan meliputi: 1) Standar Kompetensi Lulusan; 2) Standar Isi; 3) Standar Proses; 4) Stanadar Penilaian; 5) Standar Pendidik dan Tenaga Kependidikan; 6) Standar Sarana dan Prasarana; 7) Standar Pengelolaan; dan 8) Standar Pembiayaan. Salah satu upaya pemerintah untuk memenuhi standar nasional pendidikan tersebut dengan melalui Direktorat Pembinaan Sekolah Menengah Atas, Direktorat Jenderal Pendidikan Dasar dan Menengah, Kementerian Pendidikan dan Kebudayaan menyelenggarakan program sekolah rujukan bagi jenjang pendidikan dasar dan menengah dan salah satunya adalah program SMA Rujukan.

Penyelenggaraan program tersebut diperkuat dengan adanya Undang-Undang Peraturan Pemerintah Nomor 19 tahun 2005 tentang Standar Nasional Pendidikan pasal 54 ayat (1) menjelaskan bahwa pengelolaan satuan pendidikan dilaksanakan secara mandiri, efisien, efektif, dan akuntabel. Sekolah diberi kewenangan dan peran yang luas untuk merancang dan melaksanakan pendidikan sesuai dengan potensi dan kondisinya masing-masing dengan tetap mengacu pada standar minimal yang ditetapkan pemerintah melalui Standar Nasional Pendidikan (SNP). Direktorat Pembinaan SMA (2016: 13) bahwa, SMA Rujukan adalah SMA yang telah memenuhi atau melampaui SNP, mengembangkan ekosistem sekolah yang kondusif sebagai tempat belajar, mengembangkan praktik terbaik dalam peningkatan mutu berkelanjutan, melakukan inovasi dan berprestasi baik akademik maupun non akademik, serta melaksanakan program kebijakan pendidikan yang layak menjadi rujukan SMA lain.

Menurut Direktorat Pembinaan SMA (2016) Program tersebut tersebut dicanangkan oleh pemerintah dengan memiliki maksud dan tujuan, yakni : 1) Meningkatnya daya inisiatif sekolah untuk memenuhi dan melampaui Standar Nasional Pendidikan; 2) Optimalnya potensi sumber daya sekolah dan masyarakat untuk meningkatkan mutu pendidikan; 3) Berkembangnya praktik-praktik terbaik (best practices) penyelenggaraan pendidikan yang dapat dirujuk sekolah lain; 4) Terbangunnya sinergi pembinaan sekolah bermutu dengan pemerintah daerah; 5) Terwujudnya perluasan dan percepatan ketersediaan pelayanan pendidikan yang bermutu tinggi; 6) Terjalinnya kemitraan dengan berbagai pihak dalam mengembangkan sekolah.

Menurut (Mulyasa, 2002) Implementasi merupakan suatu proses penerapan ide, konsep, kebijakan atau inovasi dalam suatu tindakan praktis sehingga memberikan dampak, baik berupa perubahan pengetahuan, keterampilan maupun nilai dan sikap. Implementasi program harus dioperasionalkan dengan baik agar tercapainya suatu tujuan serta terpenuhinya visi dan misi program untuk mewujudkan sekolah yang efektif dan efisien. Menurut (Komariah \& Triatna, 2005) sekolah efektif adalah sekolah yang mampu mengoptimalkan semua masukan dan proses bagi ketercapaian output pendidikan, yaitu prestasi sekolah, terutama prestasi siswa yang ditandai dengan dimilikinya semua kemampuan berupa kompetensi yang dipersyaratkan di dalam belajar. Program sekolah rujukan ini juga mengoptimalkan input, proses, dan output yang memiliki tingkat kesesuaian antar hasil yang dicapai dengan rencana dan yang telah ditetapkan dengan memberdayakan semua 
komponen sekolah untuk mencapai tujuan sekolah secara efektif yaitu mampu memberikan pembinaan kepada sekolah imbas mengenai program unggulan yang dimiliki sekolah rujukan sehingga terjalinnya kemitraan dengan berbagai pihak dalam mengembangkan sekolah.

Ketua Panitia Sosialisasi SMA Rujukan (2017) mengungkapkan bahwa terdapat 5 SMA Rujukan di Surabaya yaitu, SMAN 2 Surabaya, SMAN 5 Surabaya, SMA ALHikmah, SMA Khadijah, dan SMA Muhammadiyah 2 Surabaya salah satu sekolah yang ditunjuk pemerintah untuk melaksanakan program SMA Rujukan di Kota Surabaya. Perbedaan dengan keempat sekolah lainnya yaitu, SMAN 5 Surabaya dan SMA Khadijah memiliki program unggulan mengenai kewirausahaan, SMAN 2 Surabaya dan Al-Hikmah memiliki program unggulan mengenai literasi/budaya membaca. SMA Muhammadiyah 2 Surabaya memiliki keunikan lain yakni memiliki program unggulan membatik bagi siswanya. Dasar ditunjuknya SMA Muhammadiyah 2 Surabaya menjadi SMA Rujukan karena SMA Muhammadiyah 2 Surabaya telah memenuhi Standar Nasional Pendidikan (SNP), memiliki ekosistem sekolah yang kondusif, mengembangkan praktik terbaik untuk meningkatkan mutu, melakukan inovasi, dan melaksanakan program kebijakan pendidikan sebaagai sekolah rujukan.

Berdasarkan studi pendahuluan yang telah dilakukan oleh peneliti, Wakil Kepala Kurikulum menjelaskan bahwa program sekolah rujukan pertama dilaksanakan pada tahun 2016 dan SMA Muhammadiyah 2 Surabaya merupakan satu-satunya sekolah yang memiliki program batik lukis di Jawa Timur. Tujuan adanya sekolah rujukan yang dilaksanakan SMA Muhammadiyah 2 Surabaya untuk menjadi percontohan/rujukan dan pembinaan bagi sekolah imbas khususnya pada kegiatan membatik. SMA Muhammadiyah 2 Surabaya memiliki banyak prestasi pada bidang seni budaya khususnya membatik yaitu, Juara I Festival Batik Lukis Tahun 2016, Juara II Festival Guru Seni Internasional Tahun 2017. Selain itu, siswa-siswi SMA Muhammadiyah 2 Surabaya sudah melakukan pameran batik lukis di berbagai tempat seperti di Museum Tugu Pahlawan dengan tema "Surabaya Kotaku", pameran batik lukis di BG Junction pada acara Hari Batik Nasional, dan bekerja sama dengan hotel Luminor Surabaya. Prestasi-prestasi tersebut yang mendorong SMA Muhammadiyah 2 Surabaya ditunjuk kembali menjadi sekolah rujukan dengan program unggulan membatik.

Sekolah yang sudah menjadi binaan dalam kegiatan membatik yaitu SMA Muhammadiyah 1,3, 4, 7, 9, 10 dan SMA Maryam. Kegiatan membatik yang diperuntukkan sekolah imbas dilakukan setiap hari jumat dan sabtu Pukul 13.0016.00 yang dilaksanakan di SMA Muhammdiyah 2 Surabaya. Kegiatan membatik termasuk muatan wajib yang dimasukkan di mata pelajaran Seni Budaya. Kegiatan membatik ini juga diberikan di kelas internasional yang merupakan kelas bilingual yang didalamnya terdapat sejumlah pelajar dari Lorne-Ayres Inlet P-12 Collage, Vitoria, Australia. Kegiatan tersebut merupakan bagian dari program pertukaran pelajar antara SMA Muhammadiyah 2 Surabaya dan Lorne-Ayres Inlet P-12 Collage, Vitoria, Australia untuk mempererat hubungan kemanusiaan dan budaya antara kedua negara.

Alasan lain memilih kegiatan membatik karena batik pada zaman sekarang sudah menjadi kearifan lokal yang harus dilestarikan keberadaanya. Alasan tersebut didukung dengan adanya Kongres Kebudayaan Indonesia 2018 yang akan segera dilaksanakan. Menurut Direktur Jenderal Kebudayaan Kementerian Pendidikan dan Kebudayaan Hilmar Farid (2018) Ada dua amanat Kongres Kebudayaan Indonesia (KKI) 2018, yaitu penyusunan Strategi Kebudayaan 20 tahun ke depan yang disampaikan kepada Presiden untuk ditetapkan dan Revolusi Kongres yang akan diimplementasikan segera. Salah satu resolusi yang sesuai dengan penelitian ini yakni terdapat pada Resolusi kedua yaitu memastikan terjadinya alih pengetahuan dan regenerasi melalui pelindungan dan pengembangan karya kreatif untuk kesejahteraan para pelaku budaya, serta perlibatan maestro dalam pendidikan dan pembelajaran formal. Resolusi merinci agenda Strategi 
Kebudayaan kedua, melindungi dan mengembangkan nilai, ekspresi, dan praktik kebudayaan tradisional untuk memperkaya kebudayaan nasional. Oleh karena itu penyelenggaraan program sekolah rujukan melalui kegiatan membatik ini merupakan salah satu upaya untuk mewujudkan keterlibatan kebudayaan tradisional ke dalam pendidikan dan pembelajaran formal. (kompas edisi 11 Desember 2018, diakses pada 12 Desember 2018).

World Health Organization (Rustamadji, 2017) mendefinisikan bahwa kecakapan hidup sebagai keterampilan atau kemampuan untuk dapat beradaptasi dan berperilaku positif, yang memungkinkan seseorang mampu menghadapi berbagai tuntutan dan tantangan dalam kehidupan secara lebih efektif. Definisi lain menurut (Anwar, 2006) kecakapan hidup merupakan kemampuan komunikasi secara efektif, kemampuan mengembangkan kerja sama, melaksanakan peranan sebagai warga negara yang bertanggung jawab, memiliki kesiapan serta kecakapan untuk bekerja, dan memiliki etika serta karakter untuk terjun ke dunia kerja. Sama halnya dengan kegiatan membatik yang dilaksanakan di SMA Muhammadiyah 2 Surabayan yang memiliki tujuan utama seperti pendidikan kecakapan hidup yaitu untuk mempersiapkan peserta didik agar memiliki kemampuan, kesanggupan, dan keterampilan yang diperlukan dalam kehidupan sehari-hari dan dapat mengembangkan dirinya, sehingga mampu mengatasi berbagai permasalahan dalam kehidupan.

Penyelenggaraan suatu program dibutuhkan pengimplementasian yang baik di dalamnya guna mencapai tujuan dari program tersebut. Sama halnya dengan implementasi program sekolah rujukan melalui kegiatan membatik dalam perspektif sekolah efektif di SMA Muhammadiyah 2 Surabaya, dibutuhkan untuk mengetahui perencanaan dari kegiatan membatik sebagai program unggulan dari sekolah rujukan, pelaksanaan program sekolah rujukan, serta dampak yang didapatkan oleh sekolah imbas setelah menjadi binaan sekolah rujukan dalam kegiatan membatik untuk menjadikan sekolah agar dapat mencapai hasil yang diharapkan sesuai dengan tujuan dari sekolah efektif.
Berdasarkan rasional peneliti yang didasari oleh landasan yuridis, empiris, dan teoritis maka hal tersebut dianggap perlu dilakukan penelitian. Peneliti beranggapan bahwa program sekolah rujukan dengan program unggulan membatik menjadikan sekolah ini memiliki konsep yang berbeda. Program sekolah rujukan melalui membatik ini merupakan salah satu aspek sekolah efektif dalam program pendidikan atau kurikulum yang diperlukan dalam menentukan keberhasilan sekolah. Untuk itu peneliti tertarik untuk melakukan penelitian dengan judul "Implementasi Program Sekolah Rujukan melalui Kegiatan Membatik dalam Perspektif Sekolah Efektif di SMA Muhammadiyah 2 Surabaya".

\section{METODE}

Penelitian ini menggunakan pendekatan kualitatif dengan rancangan penelitian Studi Kasus. Alasan peneliti menggunakan rancangan studi kasus karena dengan menggunakan pendekatan studi kasus peneliti dapat melakukan penelitian yang mendalam untuk mengungkap fenomena dan menganalisis tentang program sekolah rujukan melalui kegiatan membatik di SMA Muhammdiyah 2 Surabaya. Penelitian ini berupaya menelaah sebanyak mungkin data mengenai subjek yang diteliti. Penelitian ini menggunakan studi kasus karena ingin menyelidiki kasus secara intensif dan kemudian mendeskripsikannya. Menurut Yin (Mukhtar \& Pd, 2013) bahwa, Studi kasus adalah salah satu metode penelitian ilmu sosial. Studi kasus dipilih karena penelitian hanya memiliki sedikit peluang untuk mengontrol peristiwa yang diangkat dan kasus tersebut menekankan pada segi proses yang membutuhkan pengamatan yang menyeluruh dan mendalam. Upaya pengembangan sekolah rujukan dilakukan dengan cara mendorong sekolah untuk mengembangkan amanat pada revolusi Kongres Kebudayaan Indonesia (KKI) 2018 dalam pendidikan dan pembelajaran formal, salah satunya melalui kegiatan membatik yang dilaksanakan di SMA Muhammadiyah 2 Surabaya.

Penelitian ini dilakukan di SMA Muhammadiyah 2 Surabaya, yang beralamat Jl. Pucang Anom No. 91, Kertajaya, Gubeng, Surabaya, Jawa Timur. Teknik pengumpulan data menggunakan wawancara, observasi, 
dan dokumentasi. Penelitian ini menggunakan wawancara semi terstruktur, Informan dalam penelitian ini antara lain : Kepala Sekolah SMA Muhammadiyah 2 Surabaya, Kepala Sekolah SMA Muhammadiyah 7 Surabaya (sekolah imbas), Ketua/Koordinator Program Sekolah Rujukan, Wakil Kepala Bidang Kurikulum, Guru Membatik, Guru Sekolah Imbas/Guru Pendamping, dan Siswa Pembinaan Membatik. Penelitian ini menggunakan observasi non partisipan, dokumen-dokumen yang dijadikan sumber data dalam penelitian ini adalah profil SMA Muhammadiyah 2 Surabaya, laporan program SMA Rujukan, Surat Keputusan Kepala SMA Muhammadiyah 2 Surabaya tentang Panitia Program Sekolah Rujukan, daftar sekolah imbas serta dokumen-dokumen lainnya yang menunjang fokus penelitian.

(Huberman, Miles, \& Saldana, 2014) mengemukakan bahwa menganalisis data dengan tiga langkah yaitu kondensasi data, menyajikan data, dan menarik kesimpulan atau verifikasi. Data yang diperoleh kemudian dianalisis dengan kondensasi, penyajian data dan verifikasi data. Pengecekan keabsahan data dengan menggunakan Uji kredibilitas (Triangulasi teknik, triangulasi sumber serta membercheck), Uji Transferabilitas, Uji Dependabilitas dan Uji Konfirmabilitas. Tahap-Tahap penelitian menggunakan Tahap Pra Lapangan, Tahap Kegiatan Lapangan, Tahap Analisis Data.

\section{HASIL DAN PEMBAHASAN \\ Mendeskripsikan Perencanaan Program Sekolah Rujukan melalui Kegiatan Membatik dalam Perspektif Sekolah Efektif di SMA Muhammadiyah 2 Surabaya}

Program sekolah rujukan melalui kegiatan membatik di SMA Muhammadiyah 2 Surabaya mulai diterapkan sejak awal diluncurkannya program sekolah rujukan pada tahun 2016. Secara umum, program sekolah rujukan merupakan suatu penyelenggaraan yang dimaksudkan sebagai salah satu upaya pembinaan sekolah oleh pemerintah secara langsung untuk percepatan dan perluasan peningkatan mutu pendidikan. Program sekolah rujukan ini ada di jenjang dasar dan menengah. Untuk pada jenjang menengah, khususnya Sekolah Menengah Atas (SMA) di kelola oleh Direktorat Pembinaan SMA dan ditunjuknya sekolah rujukan ini berdasarkan kriteria yang telah ditentukan.

Berdasarkan hasil penelitian bahwa proses awal SMA Muhammadiyah 2 Surabaya menjadi sekolah rujukan yaitu diusulkan oleh Dinas Pendidikan yang tentunya harus memenuhi kriteria. Kriterianya yaitu harus menjadi pelaksana k13, sekolah mempunyai akreditasi $A$ atau terbaik di kotanya, mempunyai prestasi akademik maupun non akademik, mempunyai keunggulan yang bisa diimbaskan ke sekolah lain. Setelah kriteria tersebut terpenuhi dari daerah lalu diseleksi di pusat berdasarkan pemenuhan SNP. Menurut Direktorat Pembinaan SMA (2016 : 13) bahwa, krietria SMA Rujukan adalah SMA yang telah memenuhi atau melampaui SNP, mengembangkan ekosistem sekolah yang kondusif sebagai tempat belajar, mengembangkan praktik terbaik dalam peningkatan mutu berkelanjutan, melakukan inovasi dan berprestasi baik akademik maupun non akademik, serta melaksanakan program kebijakan pendidikan yang layak menjadi rujukan SMA lain. Sebagai sekolah rujukan, SMA Muhammadiyah 2 Surabaya memiliki kewajiban untuk memiliki programprogram unggulan yang dapat diimbaskan ke sekolah lain.

Dalam merumuskan program sekolah rujukan, harus ada perencanaan agar program dapat berjalan sesuai dengan tujuan yang diharapkan. Perencanaan adalah langkah awal sebelum mengimplementasikan suatu program agar program tersebut dapat berjalan dengan baik. (Terry \& Smith, 1990) mengungkapkan bahwa, perencanaan adalah penetapan pekerjaan yang harus dilaksanakan oleh kelompok untuk mencapai tujuan yang telah digariskan. Perencanaan mencakup kegiatan pengambilan keputusan dan pemilihan alternatif-alternatif keputusan. Pada tahap perencanaan ini diperlukan kemampuan untuk mengadakan visualisasi dan melihat ke depan guna merumuskan suatu pola dari himpunan tindakan untuk masa mendatang. Berdasarkan hasil penelitian perencanaan program sekolah rujukan yakni dengan adanya evaluasi dari 
pusat yang dilihat dari pelaporan yaang dibuat oleh SMA Muhammdiyah 2 Surabaya (Smamda). Jika lanjut menjadi sekolah rujukan, SMA Muhammadiyah 2 Surabaya akan dikirim SK untuk ditunjuk dan Kepala Sekolah akan diundang untuk membuat program dan anggaran. Kepala sekolah akan membentuk panitia dan menjelaskan rancangan program yang akan dilaksanakan. Sehingga pemerintah melihat kesesuaian antara rencana dengan pelaksanaanya.

Perencanaan program sekolah rujukan di SMA Muhammadiyah 2 Surabaya mengacu pada hasil evaluasi yang dilakukan terhadap pelaksanaan program di tahun sebelumnya dan pelaporannya. Hal ini sesuai dengan penelitian relevan yang dilakukan oleh Nining (Mariyaningsih, 2016). Dimana hasil dari penelitian tersebut menunjukkan bahwa dengan adanya kerjasama tim yang bagus, adanya komitmen bersama untuk mensukseskan program, keterbukaan anggaran, SDM dan sarana prasarana memadai merupakan faktor-faktor yang mempengaruhi keberhasilan dari penerapan program sekolah rujukan. Dengan adanya evaluasi sebelum perencanaan, sekolah dapat siap untuk menghadapi kendala atau hambatan pada pelaksanaan berikutnya. Sehingga SMA Muhammadiyah 2 Surabaya dalam perencanaan program sekolah rujukan melalui kegiatan membatik sangat memperhatikan hasil evaluasi kegiatan sebelumnya supaya program dapat berjalan sesuai dengan harapan.

Program sekolah rujukan yang diimbaskan salah satunya adalah kegiatan membatik. Berdasarkan temuan data memilih batik sebagai program unggulan yang diimbaskan adalah membatik salah satu budaya Indonesia yang harus dipertahankan meskipun perkembangan teknologi sangat pesat karena membatik merupakan warisan budaya Indonesia. Dalam membatik juga membutuhkan ketekunan, keterampilan, terdapt banyak pesan atau pembelajaran yang didapatkan ketika belajar membatik. Membatik juga masuk dalam kurikulum dalam mata pelajaran seni budaya. Sesuai dengan hasil penelitian faktor-faktor yang mempengaruhi membatik masuk dalam kurikulum sekolah adalah adanya kurikulum 2013 yang didalamnya memiliki branding bahwa sekolah harus mempunyai kearifan lokal, karena surabaya terkenal dengan membatik maka dimasukkanlah kegiatan membatik ke dalam kurikulum yang dikemas didalam mata pelajaran seni budaya. Batik yang diajarkan kepada siswa maupun sekolah imbas adalah batik lukis yang di dalam pelaksanaan pembelajaran hanya dilaksanakan di SMA Muhammadiyah 2 Surabaya dari seluruh sekolah di Jawa Timur. Hal tersebut juga imbaskan ke sekolah-sekolah sekitar dengan melakukan pembinaan kegiatan membatik sehingga sekolah sekitar juga merasakan dapat merasakan hal yang sama.

Keterlibatan kepala sekolah dalam program sekolah rujukan melalui kegiatan membatik di SMA Muhammadiyah 2 Surabaya dapat dilihat dari peran serta kepala sekolah dalam memberikan pengarahan, pembekalan, dan motivasi untuk sekolah imbas. Berdasarkan hasil penelitian bahwa SMA Muhammadiyah 2 Surabaya sangat berperan penting dalam kegiatan sekolah rujukan, oleh karena itu dipilih sekolah yang benar-benar memiliki keunggulan, berprestasi, dan sekolah yang mampu mengembangkan dan mengimbaskan program yang dimiliki sekolah ke sekolah lain. Program ini merupakan usaha pemerintah untuk percepatan pendidikan, sehingga harapan pemerintah sekolah disekitarnya dapat maju bersama dan merasakan dampak dari adanya program dari sekolah rujukan.

SMA Muhammadiyah 2 Surabaya juga memiliki peranan penting dalam tahap perencanaan program sekolah rujukan melalui kegiatan membatik. Mulai dari menyusun rencana awal kegiatan, membagi deskripsi pekerjaan yang menaungi kegiatan membatik tersebut, pemilihan sekolah imbas, persiapan sarana dan prasarana, serta terlibat langsung dalam proses pelaksanaannya. Dari temuan data penelitian Salah satu alasan batik diajukan sebagai program unggulan sekolah rujukan adalah banyaknya prestasi dalam kegiatan membatik baik prestasi yang di raih guru maupun siswa. Oleh karena itu SMA Muhammadiyah 2 Surabaya dapat dikatakan sudah mencapai sekolah efektif. Hal tersebut didukung dengan pernyataan (Priansa \& Somad, 2014) bahwa, sekolah efektif adalah 
sekolah yang mempertunjukkan standar tinggi pada prestasi akademis maupun non akademis dan mempunyai suatu kultur yang berorientasi kepada tujuan yang ingin dicapai dan hal tersebut ditandai dengan adanya rumusan visi yang ditetapkan dan dipromosikan bersama antar warga sekolah yang terdiri dari kepala sekolah, guru, staf, pegawai lainnya, komite sekolah, peserta didik, serta stakeholder lainnya.

Beradasarkan hasil temuan data, rencana awal kegiatan pembuatan RKS Kepala Sekolah membentuk tim yang namanya pengembangan membuat RKS atau pengembangan kurikulum dengan mengambil dari 8 SNP (Standar Nasional Pendidikan) dan standar al-islam dan kemuhammadiyahan. Disahkan menjadi RKS kemudian ke RKAS untuk menjadi pedoman. Untuk pembentukan panitia ditunjuk oleh sekolah dan terdapat penanggung jawab masing-masing di setiap kegiatan. Panitia ini yang bertugas untuk menentukan sekolah imbas untuk dilakukan pembinaan kegiatan membatik. Sekolah imbas yang telah terpilih yakni SMA Muhammadiyah 1, 3, 4, 7, 9, 10 Surabaya, SMA Maryam, NSA. Fasilitas sudah disediakan oleh SMA Muhammadiyah 2 Surabaya yang disesuaikan dengan anggaran dari pemerintah dan dana dampingan dari sekolah. Tahap-tahap perencanaan tersebut dilakukan oleh SMA Muhammadiyah 2 Surabaya tersebut juga sesuai dengan tahap penataan dalam buku panduan Direktorat Pembinaan SMA (2016) bahwa tahap penataan dilakukan pada tahun pertama. Kegiatan yang dilakukan adalah persiapan, penyusunan program, konsolidasi, sosialisasi, asistensi, dan sinkronisasi program. Sekolah melakukan persiapan dengan mengumpulkan data dan informasi lengkap mengenai kondisi sekolah yang terkait dengan ruang lingkup program SMA Rujukan.

\section{Mendeskripsikan Implementasi Program Sekolah Rujukan melalui Kegiatan Membatik dalam Perspektif Sekolah Efektif di SMA Muhammadiyah 2 Surabaya \\ Implementasi program sekolah rujukan melalui kegiatan membatik di SMA Muhammadiyah 2 Surabaya dilaksanakan}

sesuai dengan perencanaan yang telah dirumuskan pada tahap penataan. Implementasi sejalan dengan pelaksanaan suatu program sesuai dengan teori yang diungkapkan oleh (Budi, 2009) bahwa implementasi sejalan dengan pengertian pelaksanaan yang merupakan aktivitas menjalankan perencanaan yang sudah ditetapkan sebelumnya, sehingga program kegiatan yang sudah direncanakan akan dilaksanakan dengan sebaik mungkin untuk mendapatkan hasil yang diharapkan. Berdasarkan temuan penelitian yang didapatkan di lapangan bahwa program sekolah rujukan sangat bermanfaat untuk sekolah-sekolah terutama sekolah muhammmadiyah karena untuk meningkatkan kualitas mutu pendidikan dengan program-programnya dan sekolah imbas dapat merasakan program yang kita punya sehingga bisa diberikan kepada sekolah lain dan bermanfaat terutama untuk guru dan siswanya. Pelaksanan program sekolah rujukan melalui kegiatan membatik diawali dengan workshop atau pengarahan yang dilakukan oleh SMA Muhammadiyah 2 Surabaya yang mengundang guru dan siswa sekolah imbas dengan harapan mereka dapat mengembangkan sendiri.

SMA Muhammadiyah 2 Surabaya memiliki nilai-nilai ditanamkan di sekolah. Salah satu nilai tersebut adalah creative (berkreasi) yang artinya memberikan kesempatan untuk berkreasi sehingga siswa memiliki kemampuan untuk menciptakan sesuatu yang baru, melahirkan ide atau produk baru, dan mampu memanfaatkan peluang baru. Dari nilai yang ditanamkan tersebut dapat dikolerasikan dengan adanya kegiatan membatik yang dilaksankan di SMA Muhammadiyah 2 Surabaya. Kegiatan membatik ini dapat merupakan suatu wadah bagi siswa untuk mengasah kreativitas dan kemampuannya dibidang seni. Siswa dapat menuangkan ide-ide baru untuk menghasilkan suatu produk berupa hasil karya batik lukis. Selain itu dengan adanya pembinaan membatik, siswa juga dapat menciptakan peluang baru dengan memanfaatkan kemampuannya dibidang membatik untuk berwirausaha. Sehingga nilai-nilai yang ditanamkan di SMA Muhamadiyah 2 Surabaya sangat relevan dengan program kegiatan yang 
dilaksanakan, terutama pada pembinaan kegiatan membatik yang mencerminkan adanya nilai creative (berkreasi) di dalamnya.

Pelaksanaan program sekolah rujukan melalui kegiatan membatik merupakan kegiatan yang dilakukan sesuai dengan rencana yang telah ditetapkan dan dijadwalkan di awal program. Sama halnya dengan program sekolah rujukan melalui kegiatan membatik ini juga dilakukan secara berkesinambungan karena melakukan suatu kebijakan. Menurut (Sanusi, 1988) bahwa implementasi kebijahaj merupakan proses menjalankan, menyelenggarakan dan mengupayakan alternatif yang telah diputuskan berdasarkan hukum yang berlaku. Hal tersebut didukung dengan penelitian penelitian relevan yang dilakukan oleh (Ekawati, 2017) , dimana hasil dari penelitian tersebut menunjukkan bahwa kebijakan sekolah rujukan yaitu untuk memberikan pembinaan bagi sekolah imbas yang berkeinginan untuk belajar tentang segala sesuatu yang lebih unggul dari sekolah imbas tersebut. Sesuai dengan hasil temuan data penelitian di lapangan, kepala SMA Muhammadiyah 2 Surabaya juga mengatakan mengenai kegiatan membatik bahwa kebijakannya wajib diajarkan untuk seluruh siswa, harus mampu mengembangkan kegiatan membatik ini, harus mampu mengimbaskan batik-batik Muhammadiyah ini ke masyarakat, dan kegiatan membatik masuk di kurikulum baik intra maupun ekstra. Dengan adanya kebijakan yang dilakukan oleh kepala sekolah diharapkan pelaksanaan dapat berjalan secara optimal. Pernyataan tersebut didukung oleh hasil penelitian dari (Mawardi, 2017) yang menunjukkan bahwa Kepala sekolah selaku pemimpin sekolah hendaknya dapat memimpin semua personil sekolah, sehingga mereka dapat menjalankan semua tugas dengan baik. Guru hendaknya dapat menjadi pendidik dan pengajar yang komunikatif bagi siswanya.

Pelaksanaan kegiatan membatik ini sudah dilakukan selama hampir 5 tahun sebelum program sekolah rujukan ada, SMA Muhammadiyah 2 Surabaya (Smamda) sudah menerapkan batik lukis Smamda. Setelah adanya program sekolah rujukan melalui kegiatan membatik, pembinaan membatik lebih diperluas dengan adanya sekolah imbas sebagai pesertanya. Berdasarkan hasil temuan penelitian yang telah dilakukan oleh peneliti, sistem pelaksanaan program sekolah rujukan melalui kegiatan membatik dilaksanakan sesuai jadwal yang telah ditentukan oleh SMA Muhammadiyah 2 Surabaya selaku sekolah rujukan dan penyelenggara program. Program sekolah rujukan melalui kegiatan membatik dilaksanakan 2-3 bulan sekali setiap hari Jumat dan Sabtu, untuk hari Jumat dilaksanakan pukul 13.00 WIB s.d. 16.00 WIB dan untuk hari Sabtu dilaksanakan pukul 08.00 WIB s.d. 11.00 WIB. Pembinaan kegiatan membatik dilaksanakan selama 10 kali pertemuan dengan peserta yang berasal dari SMA Muhammadiyah 2 Surabaya selaku sekolah rujukan dan sekolah-sekolah imbas yang terpilih. Setiap sekolah mengirimkan 5-10 peserta dan 2 guru pendamping.

Pelaksanaan program sekolah rujukan mencakup semua kegiatan yang telah ditetapkan menjadi program-program unggulan yang akan diimbaskan ke sekolahsekolah lain. Pelaksanaan program sekolah rujukan dijalankan sesuai dengan perencanaan yang telah dirumuskan agar setiap kegiatan yang dilakukan memiliki arah dan tujuan. Dalam tahap pelaksanaan ini harus adanya apresasi yang didapatkan peserta atau siswa yang mengikuti kegiatan. Sebagai contohnya berdasarkan hasil penetian pada program sekolah rujukan melalui kegiatan membatik ini, SMA Muhammadiyah 2 Surabaya memberikan apresiasi kepada siswa/peserta pembinaan membatik dengan mengadakan pemeran dan pemberian sertifikat. Hal tersebut sesuai dengan pernyataan dari (Terry \& Smith, 1990) yang mengungkapkan bahwa tahap pelaksanaan yang disebut juga "gerakan aksi" ini mencakup kegiatan yang dilakukan seorang manager untuk mengawali dan melanjutkan kegiatan yang ditetapkan pada tahap perencanaan agar tujuan-tujuan dapat tercapai. Tahap pelaksanaan mencakup beberapa kegiatan yaitu penetapan dan pemuasan kebutuhan manusiawi dari pegawai-pegawainya, memberikan reward (penghargaan),

memimpin, mengembangkan, dan memberikan kompensasi untuk para pegawai. Pernyataan tersebut menyatakan bahwa seoarang manager memiliki andil yang besar 
untuk mengatur dan mencapai hal-hal yang telah direncanakan dapat terlaksana dengan baik. Seorang manager dalam program sekolah rujukan melalui kegiatan membatik yakni penanggung jawab dari kegiatan yang bersangkutan yakni Pak Rachmad dan Pak Didit selaku penanggung jawab kegiatan pelatihan dan pameran batik lukis dan guru membatik di SMA Muhammdiyah 2 Surabaya.

Pembelajaran membatik ini termasuk dalam pendidikan kecakapan hidup atau (life skill education) karena membatik merupakan suatu kegiatan yang dimasukkan ke pendidikan formal dalam mata pelajaran seni budaya agar siswa memiliki kemampuan keterampilan di kehidupan sehari-hari. Hal tersebut juga dijelaskan oleh (Rustamadji, 2017) bahwa terdapat hubungan antara mata pelajaran, kecakapan hidup, dan kehidupan nyata. Berdasarkan temuan penelitian bahwa pelaksanaan pembinaan kegiatan membatik memiliki tujuan agar siswa agar memiliki kemampuan, kesanggupan, dan keterampilan yang diperlukan dalam kehidupan sehari-hari dan dapat mengembangkan dirinya untuk memiliki orientasi hidup ke arah masa depan.

Dalam setiap kegiatan yang dilaksanakan pasti terdapat kendala yang dihadapi, sama halnya dengan program sekolah rujukan melaui kegiatan membatik ini. Berdasarkan hasil temuan di lapangan bahwa kendala yang dihadapi selama proses pelaksanaan pembinaan sekolah rujukan melalui kegiatan membatik di SMA Muhammadiyah 2 Surabaya adalah sekolah imbas yang hanya memiliki guru seni satu yang semestinya harus dua, minat siswa untuk membatik perlu ditambah, kenaikan bahan untuk membatik seperti kompor listrik yang pesan di Jogja, aktivitas siswa yang banyak dan jadwalnya berbenturan, belum adanya tempat/galeri membatik untuk penyimpangan karya siswa, dan tempat yang kurang kondusif. Kendala tersebut harus diatasi oleh SMA Muhammadiyah 2 Surabaya sebagai penyelenggara program. Dengan diketahuinya kendala yang dihadapi, sekolah dapat memperbaiki untuk memantapkan program yang telah dilaksanakan.
Dengan adanya kendala-kendala yang dihadapi tersebut, cara SMA Muhammadiyah 2 Surabaya untuk mengatasi kendala untuk program sekolah rujukan melalui kegiatan membatik adalah sekolah hanya mempunyai guru seni satu, dapat diganti dengan guru yang mempunyai kemampuan seni membatik, untuk minat siswa solusinya diperbanyak kuotanya dan dimaksimalkan pendampingnya serta memaksimalkan target membuat karya, tiap tahun harus dianggarkan dengan anggaran baru, menggunakan tempat lain terlebih dahulu agar kegiatan tetap jalan. Upayaupaya tersebut dilakukan SMA Muhammadiyah 2 Surabaya agar pembinaan kegiatan membatik dapat tetap berjalan dengan baik dengan adanya kerjasama dan dukungan antara semua pihak yang terkait dengan program sekolah rujukan melalui kegiatan membatik ini.

Program sekolah rujukan melalui kegiatan membatik mendapat banyak dukungan yaitu dari sekolah, komite, dinas pendidikan dan masyarakat, karena kegiatan membatik ini bukan hanya program sekolah namun juga program pemerintah untuk melestarikan budaya Indonesia. Semua pihak SMA Muhammadiyah 2 Surabaya selaku menyelenggara program memiliki andil besar dalam memberi banyak dukungan, baik dukungan moral maupun material. Karena berdasarkan hasil wawancara dengan salah satu informan bahwa untuk pembinaan membatik terdapat banyak biaya-biaya yang tidak terduga. Sehingga sekolah rujukan juga menyiapkan dana dampingan yang anggarannya berasal dari SMA Muhammadiyah 2 Surabaya agar pembinaan kegiatan membatik dapat terlaksana secara optimal. Dukungan yang diberikan dari semua pihak tersebut merupakan bentuk kepedulian agar pelaksanaan program sekolah rujukan melalui kegiatan membatik dapat terealisasikan dengan baik dan menimbulkan dampak yang baik pula untuk sekolah rujukan maupun sekolah imbas. 


\section{Mendeskripsikan Dampak dari Program Sekolah Rujukan melalui Kegiatan Membatik dalam Perspektif Sekolah Efektif di SMA Muhammadiyah 2 Surabaya}

Dampak dari adanya program sekolah rujukan melalui kegiatan membatik dapat dirasakan baik bagi sekolah rujukan maupun bagi sekolah imbas. SMA Muhammadiyah 2 Surabaya sebagai penyelenggara program sekolah rujukan melalui kegiatan membatik memiliki andil yang besar dalam terwujudkan tujuan dari program sekolah rujukan yang dicanangkan oleh pemerintah. SMA Muhammadiyah 2 Surabaya juga dapat dikatakan sebagai sekolah yang efektif karena memiliki dampak yang besar dalam menyukseskan program sekolah rujukan ini. Hal tersebut diperkuat dengan adanya pernyataan dari (Suharsaputra, 2010) yang menjelaskan bahwa sekolah efektif dapat diartikan sebagai sekolah yang mempunyai efek atau dampak signifikan bagi terwujudnya tujuan yang diharapkan. Dari pernyataan tersebut dapat diketahui bahwa memang SMA Muhammadiyah 2 Surabaya mempunyai efek dan dampak yang signifikan dalam terlaksananya program sekolah rujukan melalui kegiatan membatik. Karena sebagai penyelenggara, SMA Muhammadiyah 2 Surabaya menyiapkan semua dari mulai dari adanya rumusan perencanaan, pengorganisasian panitia di setiap kegiatan, adanya pengarahan dalam bentuk workshop yang dilakukan sekolah rujukan untuk sekolah imbas, proses pelaksanaan, sampai pada tahap memberikan apresiasi untuk semua peserta pembinaan membatik. Sehingga dapat disimpulkan bahwa dampak-dampak positif yang diperoleh sekolah rujukan, sekolah imbas, serta masyarakat tersebut tidak lepas dari adanya pengelolaan dan kerjasama yang baik dari semua komponen sekolah.

Salah satu tujuan dari adanya program sekolah rujukan sebagai pemerataan dan percepatan mutu pendidikan khususnya di Indonesia dan SMA Muhammadiyah 2 Surabaya sudah melakukan program sekolah rujukan melalui kegiatan membatik dengan baik. Hal tersebut dibuktikan dari best practice atau praktik-praktik terbaik yang telah dilakukan SMA Muhammadiyah 2 Surabaya yang menularkan atau mengimbaskan kegiatan membatik ke sekolah-sekolah lain. Selain itu, pencapaian prestasi dan penyelenggaraan pameran batik lukis juga pernah dilaksanakan oleh siswa program sekolah rujukan melalui kegiatan membatik ini. Prestasi tersebut tyaitu juara 1 pameran pendidikan di Jatim Expo dan telah menyelenggarakan lima kali pameran yaitu di Balai Pemuda, Taman Budaya Cak Durasim, Tugu Pahlawan, Jatim Expo, dan Mall BG Junction.

Pencapaian hal tersebut berkat ketekunan yang dilakukan siswa maupun guru saat pelaksanaan pembinaan membatik berlangsung. Semua siswa membuat karya terbaiknya untuk dipamerkan sehingga dapat mengenalkan budaya lokal ke seluruh masyarakat. Sesuai yang diungkapkan oleh Suharsaputra (2010:65) mengenai sekolah efektif dalam perspektif mutu pendidikan, dimana di dalamnya menjelaskan bahwa sekolah bermutu ditunjukkan bukan hanya dari indikator seberapa banyak siswa yang berprestasi yang dilihat dari nilai yang paling tinggi, sekolah juga perlu melihat siswanya baik dari kepemilikan kualitas pribadi, seperti tampak dalam kepercayaan diri, kemandirian, kedisiplinan, kerja keras, ulet, terampil, berbudi pekerti, beriman, dan bertaqwa, tanggung jawab, apresiasi, dan sebagainya. Pernyataan tersebut mencerminkan pelaksanaan pembinaan kegiatan membatik yang siswanya memiliki kedisiplinan, kerja keras, ulet, terampil dalam membuat karya-karya betik lukis yang terbaik. Karena dalam membatik dibutuhkan ketekunan dan keahlian untuk membuatnya. Selain itu siswa juga memiliki kepercayaan diri untuk memamerkan karya yang telah dibuatnya ke masyarakat luas, karena disamping memiliki kebanggaan tersendiri karena karya batik lukisnya dapat dilihat banyak orang, siswa juga harus menyiapkan diri apabila ada kritik dan saran yang disampaikan masyarakat saat pameran. Hal ini sesuai dengan hasil penelitian yang dilakukan oleh (Nurdin, 2011) bahwa model penilaian sekolah efektif merupakan salah satu instrumen yang diharapkan dapat digunakan oleh pengelola pendidikan untuk mengetahui tingkat keberhasilan setiap sekolah. Hasil penilaian tersebut selanjutnya dapat dijadikan pertimbangan untuk melakukan upaya perbaikan sekolah. 
Keefektifan sekolah mengidentifikasi karakteristik sekolah berpenampilan unggul (high performing schools). Seperti halnya yang disampaikan oleh (Shannon \& Bylsma, 2007) bahwa karakteristik sekolah efektif berpenampilan unggul itu meliputi: (a) Fokus bersama dan jelas; (b) Standar dan harapan yang tinggi bagi semua siswa; (c) Kepemimpinan sekolah yang efektif; (d) Tingkat kerja sama dan komunikasi inovatif; (e) Kurikulum, pembelajaran dan evaluasi yang melampaui standar; (f) Frekuensi pemantauan terhadap belajar dan mengajar tinggi; (g) Pengembangan staf pendidik dan tenaga kependidikan yang terfokus; (h) Lingkungan yang mendukung belajar; (i) Keterlibatan yang tinggi dari keluarga dan masyarakat. Hasil penelitian menunjukan bahwa kontribusi pembinaan kegiatan membatik untuk ketercapaian keefektifan sekolah di SMA Muhammadiyah 2 Surabaya yaitu perolehan prestasi dengan menjadi juara 1 di Jatim Expo yang relevan dengan teori diatas yaitu adanya standar dan harapan yang tinggi bagi semua siswa dengan pencapaian prestasi tersebut. SMA Muhammadiyah 2 Surabaya juga berkontribusi dengan menyumbangkan alat untuk pembinaan kegiatan membatik ke sekolah imbas. Hal tersebut sama dengan pernyataan teori diatas yaitu adanya tingkat kerjasama dan komunikasi yang inovatif agar sekolah imbas dapat mempratikkan sendiri kegiatan membatik di sekolah masing-masing.

Sehingga dapat ditarik kesimpulan bahwa untuk mendapatkan hasil yang memuaskan diperlukan kerjasama dan koordinasi antar semua komponen sekolah agar proses implementasi program sekolah rujukan melalui kegiatan membatik di SMA Muhammadiyah 2 Surabaya dapat berjalan secara optimal. Dengan adanya rumusan perencanaan yang baik, proses pelaksanaan yang terjadwal dan memiliki target dalam membuat suatu karya, akan diperoleh dampak yang positif baik untuk sekolah rujukan maupun sekolah imbas. jadi dengan adanya program sekolah rujukan melalui kegiatan membatik tujuan untuk pemerataan pendidikan bagi sekolah imbas dapat tercapai.

\section{KESIMPULAN}

Berdasarkan hasil penelitian terdapat beberapa pernyataan sebagai simpulan yang dapat diuraikan sebagai berikut: 1) Keefektifan pengimplementasian program sekolah rujukan melalui kegiatan membatik dalam perspektif sekolah efektif di SMA Muhammadiyah 2 Surabaya di dukung dengan adanya perencanaan program yaitu proses awal menjadi sekolah rujukan dan dasar perencanaan pelestarian budaya membatik. Kemudian adanya pengorganisasian panitia dengan melibatkan beberapa komponen sekolah yang bertugas untuk memilih sekolah imbas yang merupakan sasaran dari program sekolah rujukan dan melakukan pemenuhan sarana dan prasaran untuk pembinaan kegiatan membatik. 2) Implementasi program sekolah rujukan melalui kegiatan membatik dalam perspektif sekolah efektif di SMA Muhammadiyah 2 Surabaya di dukung dengan adanya kerjasama antara seluruh warga sekolah, komite, dan dinas pendidikan serta komponen pendukung lainnnya. Namun terdapat kendala dalam pelaksanaan yaitu berkaitan dengan tempat pembinaan membatik yang bertempat di Mushola K.H Ahmad Dahlan. Pelaksanaan pembinaan membatik dilakukan dengan memberikan pengarahan atau workshop yang mengundang guru dan siswa sekolah imbas. Jadwal pelaksanaan yaitu hari Jumat dan Sabtu dengan durasi waktu 3-4 jam per hari. Sistem pembinaan dilakukan 1 minggu 2 kali dengan intensitas 10 kali pertemuan. Setiap sekolah mengirimkan peserta sebanyak 5-10 siswa dan 2 guru pendamping. Hasil karya siswa pembinaan membatik akan diapresasi dalam bentuk pameran. Pameran dilaksanakan di Balai Pemuda, Taman Budaya Cak Durasim, Tugu Pahlawan, Jatim Expo dan BG Junction. 3) Dampak adanya program sekolah rujukan melalui kegiatan membatik yaitu bagi sekolah rujukan dapat meningkatkan citra sekolah, bagi sekolah imbas dapat meningkatkan motivasi bagi sekolah agar dapat memiliki program serupa, dan bagi siswa yaitu untuk menyalurkan bakat, minat, dan menambah wawasan tentang batik lukis serta peningkatan prestasi bidang seni khusunya seni membatik. 


\section{SARAN}

Berdasarkan paparan data, temuan penelitian, pembahasan, serta kesimpulan, maka peneliti mengemukakan saran-saran yang ditunjukan bagi: 1) Kepala Sekolah, sebagai penanggung jawab program, hendaknya selalu melakukan pengontrolan mengenai program sekolah rujukan khususnya dalam pembinaan membatik untuk mengukur dan menilai berjalannya program. Hal tersebut dilakukan sebagai bahan perbaikan program dan dapat digunakan untuk pengambilan kebijakan sehingga tujuan program sekolah rujukan melalui kegiatan membatik bisa tercapai sesuai yang diharapkan. 2) Ketua/Koordinator Program, hendaknya selalu melakukan koordinasi dan penggerakan dengan semua panitia pelaksana, tak terkecuali pada pelaksanaan pembinaan membatik agar dapat terlaksana secara optimal. 3) Wakil Kepala Bidang Kurikulum, sebagai yang merancang kegiatan membatik dimasukan ke dalam kurikulum, hendaknya terus melakukan pelaporan pelaksanaan program tersebut kepada kepala sekolah agar kegiatab membatik tetap terkontrol dengan baik. 4) Guru, adalah elemen terpenting dalam pelaksanaan program sekolah rujukan melalui kegiatan membatik. Selain mengajari secara langsung dalam pembuatan batik lukis, guru juga memberikan pembelajaran materi di kelas. Guru hendaknya membuat rencana pembelajaran sesuai dengan kurikulum yang berlaku serta membuat metode atau strategi pembelajaran yang menyenangkan bagi siswa. 5) Kepala Sekolah Imbas, hendaknya bisa dijadikan motivasi bagi sekolah imbas agar dapat melaksanakan program kegiatan yang serupa. Diiringi dengan faktor pendukung sumber daya manusia dan sarana prasarana yang memadai serta pembiayaan yang disesuaikan dengan anggaran sekolah. 6) Peneliti Lain, diharapkan dapat dijadikan referensi dan informasi dalam melakukan penelitian lain di bidang yang sama, yakni tentang implementasi program sekolah rujukan melalui kegiatan membatik dalam perspektif sekolah efektif.

\section{DAFTAR RUJUKAN}

Anwar. (2012). Pendidikan Kecakapan Hidup (Life Skills Education) Konsep dan Aplikasi. Bandung: Alfabeta.

Budi, R. (2009). Dasar-Dasar Manajemen Pendidikan. Surabaya: Lembaga Penerbit FIP UNESA.

Ekawati, Y. (2017). Implementasi Kebijakan Sekolah Dasar Rujukan di SD Negeri 1 Bantul. Skripsi. Yogyakarta: Universitas Negeri Yogyakarta.

Komariah, A. \& Triatna, C. (2010). Visionary Leadership: Menuju Sekolah Efektif. Jakarta: Bumi Aksara.

Mariyaningsih, N. (2016). Evaluasi Program Pengembangan SMK Rujukan di SMK Negeri 2 Salatiga. Skripsi. Salatiga: Universitas Kristen Satya Wacana.

Mawardi. (2017). Efektivitas Sekolah di Kabupaten Aceh Tengah Antara Kepemimpinan Situasional dan Budaya Sekolah. Jurnal Administrasi Pendidikan Volume 24 No. 2. Bandung: Universitas Pendidikan Indonesia.

Miles \& Huberman. (2014). Qualitative Data Analysis, A Methods Sourcebook. Third Edision. Sage Publication, Inc.

Mukhtar. (2013). Metode Praktis Penelitian Deskriptif Kualitatif. Jakarta: REFERENSI (GP Press Group).

Mulyasa. (2003). Kurikulum Berbasis Kompetensi. Bandung: PT Remaja Roasdakarya.

Nurdin. (2011). Manejemen Sekolah Efektif dan Unggul. Jurnal Administrasi Pendidikan, Volume 13 No. 1. Bandung: Universitas Pendidikan Indonesia.

Priansa, D. J. \& Somad, R. (2014). Manajemen Supervisi \& Kepemimpinan Kepala Sekolah. Bandung: Alfabeta.

Rustamadji, dkk. (2017). Pendidikan Kecakapan Hidup: Sebuah Filosofi 
General Education. Yogyakarta: Indomedia Pustaka.

Sanusi, A. (1988). Sistem Manajemen Pendidikan di Indonesia. Bandung: IKIP.

Shannon, G.S \& Bylsma, P. (2005). Nine Characteristics of High-Performing Schools. Office Superintendent of Public Instruction. San Francisco: Jossey Bass.

Suharsaputra, U. (2010). Administrasi Pendidikan. Bandung: PT Refika Aditama.

Terry, G. (1984). Prinsip-Prinsip Manajemen. Jakarta: PT. Bumi Akasara.

Undang-Undang Peraturan Pemerintah Nomor 19 tahun 2005 tentang Standar Nasional Pendidikan pasal 54 ayat (1). 